\title{
The Role of Supervisory Support and Life Balance Work in Increasing Organizational Citizenship Behavior: Study at Hotel Employees in Malang
}

\author{
Nilawati Fiernaningsih ${ }^{\mathrm{a}} *$; Umar Nimran ${ }^{\mathrm{b} *}$, Kusdi Raharjo ${ }^{\mathrm{c} *}$, Zainul Arifin $^{\mathrm{d} *}$ \\ ${ }^{a}$ Doctoral Student, Department of Business Administration, Faculty of Administration, Brawijaya University; b/cld Department of Business \\ Administration, Faculty of Administration, Brawijaya University, Malang, Indonesia
}

\section{ARTICLE INFORMATION}

\section{Article history:}

Data submission : September 19, 2019

$1^{\text {st }}$ revision: October 21, 2019

Accepted: November 12, 2019

Available online: December 12, 2019

Keywords: supervisory support, work life balance, organizational citizenship behavior.

\begin{abstract}
AB STRACT
The purpose of this study was to examine the effect of supervisory support on work life balance and organizational citizenship behavior. Data was collected from 209 five-star hotels and four-star hotels staff in Malang, East Java, Indonesia, using a questionnaire. Data was analyzed using GeSCA. The research findings show that supervisory support has a significant effect on work life balance, but supervisory support does not have a significant direct effect on organizational citizenship behavior. Meanwhile work life balance has a significant effect on organizational citizenship behavior. These findings provide insight to managers that employees need emotional support and instrumental so that they can balance work life with their personal lives. A good life balance work will foster organizational citizenship behavior that has an important role in improving the performance and competitiveness of the company.
\end{abstract}

2019 FIA UB. All rights reserved.

\section{Introduction}

Hotel competitiveness lies in the quality of service and human resources, which are the keys to the success of hotels in serving guests (Organ, 1988, Karatepe, 2006; Podsakoff et al., 2000). Companies need employees who are able to complete their main tasks, but also voluntarily encourage the effectiveness of organizational functions (Podsakoff et al., 2000). Employees perform job duties in accordance with its role in the organization and be able to do something beyond the role, in order to realize the expected guest service and ultimately enhance competitiveness of the corporate. Organizational Citizenship Behavior (OCB) is defined as behavior that is part of the organization as a form of work that is beyond normal expectations and can provide more services to achieve organizational goals (Rea Andre, 2008) and will be a source of corporate excellence (Jan \& Gul, 2016).
OCB has become an important study in organizations because it can realize organizational goals effectively and efficiently in the short and long term. Various studies have been conducted to examine the antecedent factors that affect $\mathrm{OCB}$, such as supervisory support (LePine et al., 2002), participation in decision making (Muhammad, 2004), job autonomy (Machuca et al., 2015), job satisfaction (Nadiri \& Tanova, 2010), and engagement (Lyu et al., 2016). The study of Work Life Balance (WLB) and its relationship with $\mathrm{OCB}$, especially in the field of hospitality, is still very necessary, considering that hotel employees are required to always provide best service to the guests. High work demands in the workplace have the potential to reduce their personal lives which can have an effect on decreasing extra work behavior. Supervisory support is also possible to make a positive contribution to employee comfort and extra work behavior.

Based on the considerations above, this study focuses on the relationship between supervisory

* Corresponding author. Tel.: +62-877-3730-7849; e-mail: nilafh@yahoo.co.id 
support, WLB, and OCB in hotel companies. The specific objectives of this study are: (1) to investigate the effect of supervisory support on the WLB; (2) to investigate the effect of supervisory support on OCB; Ana (3) to investigate the effect of WLB on OCB.

\section{Theory}

\subsection{Social exchange theory}

Social Exchange Theory is used as an approach in understanding human resource issues in business organizations today. Social exchange theory may underlie the relationship between the parties involved in the company. The principle of this theory states that if one party benefits from the other party, one party will pay by providing benefits to the other (Blau, 1964). Employees get benefits from the company not only in the form of financial benefits but also in the form of non-financial benefits. Nonfinancial benefits may include supervisory support. Supervisory support is perceived as a kindness given by the company to its employees. The supervisor has a very important and vital role in the organization because it has the duty to control the entire work process and become a bridge between managerial and operator. Superiors' support for their employees will help alleviate or even reduce the stress experienced by employees at work. By supervisors' support, it will be able to divert the stress experienced by employees when faced with the demands of work, but they do not have control over the work. Supervisory support reflects the extent to which an employee's supervisor is seen as good, caring and able to provide emotional and instrumental assistance when needed (Bacharach \& Bamberger, 2007).

The kindness of the company to employees in the form of supervisory support, creates a feeling of pleasure because employees have sufficient time to balance their working lives with their personal lives. The balance between the demands of work and personal demands are important aspects are taken into account by the employees. Employees feel comfortable when the company facilitates and opens opportunities for employees to carry out work tasks without ignoring their personal lives, such as their domestic life, hobbies, and other personal activities. Work Life Balance is important in making employees feel comfortable while working. Feelings happy are a form of benefits received by employees so that employees return the favor with positive behavior, namely OCB. Employees voluntarily help other employees and organizations in improving performance and competitiveness.

\subsection{Supervisory support}

The supervisor has a very important and vital role in the organization because it has the duty to control the entire work process, staff behavior, and become a bridge between managerial and operator parties. In addition, supervisors are also required to provide support to their subordinates so that they are always motivated and show maximum performance in their work (Gillet et al., 2013). Supervisor support for employees will help alleviate or even reduce the stress experienced by employees in work (Karatepe \& Babakus, 2007; Suan \& Nasurdin, 2013; Yang et al., 2016). The support from the boss will be able to divert the stress experienced by employees when faced with the demands of work but they do not have control over the work. Supervisory support reflects the extent to which an employee's supervisor is seen as good, caring and able to provide emotional and instrumental assistance when needed (Bacharach \& Bamberger, 2007).

Bhate (2013) defines supervisory support as the extent to which leaders assess employee contributions and care about employee welfare. Employees need motivation to generate greater effort, and more personal resources, in carrying out innovative tasks. When supervisors show their concern for their employees, employees also tend to receive support and attention from their supervisors. Employees who get support from supervisors often feel obliged to give reciprocation for the help or kindness provided by the supervisor by helping supervisors to achieve their intended goals. Strong supervisory support will improve the quality of employee work and it will increase employee job satisfaction, contribute positively to both employees and the organization and reduce turnover (Bhate, 2013). Supervisory behavior and support is one indicator of organizational support because a supervisor is an intermediary from an organization that is directly responsible for managing employees as subordinates. Characteristics of supervisor support shown by their tolerance for employees who are experiencing difficulties with the work assigned to them, to reward outstanding employees and provide incentives to employees with better performance. It is important for supervisors to listen and pay attention to employee complaints about various matters relating to work, even though it does not change anything but at least can make employees feel better (Wicks, 2005).

\subsection{Work life balance}

Work life balance is important as one component in creating employee work comfort because employees as individuals, not only have life in the company, but also have life as a person, life in family, life in society, and life in other organizations. Delecta (2011) defines work-life balance as the ability of individuals to fulfill work and commitment in their family life, as well as other non-work responsibilities. Meanwhile, according to Frame \& Hartog (2003), work-life balance means that employees can freely use flexible working hours to balance their work or duties with other commitments 
such as family, hobbies, arts, studies, and not only focus on their work. Work-life balance has important consequences for employee attitudes towards their organization, as well as for the lives of employees. Work life balance also means that employees can freely use flexible working hours to balance their work or duties with other commitments such as family, hobbies, arts, studies and not only focus on their work.

Kalliath and Brough (2008) describe several views of the definition of work life balance from several previous researchers. First, work-life balance defined as multiple roles. Work-life balance is seen as a dual role, where there is a bidirectional relationship. This means that in the dual role, there are positive and negative influences, both in home-to-work and workto-home relationships. Second, work-life balance defined as equity across multiple roles. The definition of work-life balance is further investigated with a focus on the balance of time or one's satisfaction in carrying out his dual role. Third, work-life balance defined as satisfaction between multiple roles. Clark (2000) argued that work-life balance is a good satisfaction activities, at home and at work, with a minimum of conflict level. Fourth, work-life balance defined as a fulfilment of role salience between multiple roles. This view focuses on work-life balance as something that has dynamics, so it may change in line with changes in an individual's life. Work-life balance defined as a relationship between conflict and facilitation. Fifth, , work-life balance defined as perceived control between multiple roles. Work-life balance can also be interpreted as a level of autonomy that an individual must have in fulfilling the demands of his dual role.

Lockwood (2003) defines work-life balance is a state of balance between two demands where the work and life of an individual are the same. Finally, Brough and Kalliath (2009) defines work life balance as to the extent to which the involvement and satisfaction of individuals in carrying out roles and psychological involvement with their roles in work life and personal life (for example with partners, parents, family, friends and members of community) and there is no conflict between the two roles. It can be said that individuals who pay attention to the life balance of work and personal life are individuals who are more concerned with their psychological wellbeing than purely pursuing wealth.

Work-life balance is a challenge for companies in creating a supportive culture within the company where employees can focus on working when they are in the workplace with the aim that employees get the opportunity to be able to balance the demands of work with household responsibilities. The essence of work life balance is the company's efforts to improve welfare, improve job satisfaction, meet family expectations and needs, and fulfill employee expectations such as a better life, a working life that is more meaningful and beneficial for him. According to Robbins and Coulter (2012) work-life balance programs include resources for parent and child care, employee health and welfare, relocation, and others. Many companies offer family-friendly benefits that employees need to balance life and work, which includes flextime, job sharing, telecommunicating and others.

Lewison (2006) mentions several advantages with the implementation of work-life balance programs. First, it reduces absenteeism. Usually the cause of lazy employees is family responsibility and personal stress factors. This problem can be overcome by setting flexible working hours. Second, reducing turnover. Flexible working hours are proven effective in maintaining employee commitment to the company. Third, increase productivity. Minimizing the level of work stress will have an effect on increasing employee work productivity. Fourth, overtime costs are reduced. Flexible work hours scheduling has a good impact on reducing overtime and stress hours which are directly proportional to reducing overtime costs and increasing employee work productivity. Fifth, client retention. Flexible working hours arrangement will make employees give more value to clients, when employees provide greater service, they will help retain clients because satisfaction from the client increases.

\subsection{Organizational citizenship behavior}

Every organization needs Organizational Citizenship Behavior to improve company performance and competitiveness. With OCB, it will increase efficiency and achieve corporate goals. Robbins (2003), argues that successful organizations need employees who work beyond their formal duties.

Organizational Citizenship Behavior according to Organ (1988) is a choice behavior that is not related to the organization's formal reward system but can increase organizational effectiveness. Dyne and Illies (2008), argues that Organizational Citizenship Behavior is an "extra-role behavior" that is beneficial for the company.

According to Podsakoff et al (2000), OCB is a discretionary individual behavior, which does not directly and explicitly get expectations from a formal reward system, and which overall drives the effectiveness of organizational functions. Schermerhorn et al. (2010) stated that, "organizational citizenship behavior is willingness to go beyond the call of duty or go to the extra mile in one 's work". Organization citizenship is the willingness to carry out work outside their obligations. Luthans (2011) defines Organizational Citizenship Behavior (OCB) as "an individualized recognition, not a formal reward system, and an 
aggregate promotion of the effective functioning of the organization.

Robbins and Coulter (2012) stated "organizational citizenship behavior (OCB) is discretionary behavior that's no part of an employee's formal job requirements, but which promotes the effective functioning of the organization". Colquitt, LePine dan Wesson (2015) stated "citizenship behavior is defined as voluntary employee activities that may or may not be rewarded but contribute to the organizational by improving the overall quality of setting in which work take place".

The benefits of OCB for organizations according to Podsakoff (2000): (1) OCB increases the productivity of coworkers; (2) OCB increases manager productivity; (3) OCB saves resources owned by management and the organization as a whole; (4) OCB helps save energy a scarce resource for maintaining group functions; (5) OCB can be an effective means of coordinating work activities. Showing civic virtue behavior (such as attending and actively participating in meetings in work units) will help coordinate among group members; (6) OCB increases the organization's ability to attract and retain the best employees; (7) improve the stability of organizational performance; (8) OCB increases the ability of organizations to adapt to environmental changes.

Factors that influence the emergence of OCB are quite complex and interrelated with each other (Organ, 1988). OCB can develop in a conducive organizational culture and climate. A boss who cares for subordinates is a supporter of creating positive employee behavior. In such situations, employees feel happy to work and are able to live a work life and personal life in a balanced manner. The implication is the emergence of positive employee behavior to help colleagues and help companies achieve their goals. George and Brief (1992) stated that one's willingness to help others also affected moods. If the organization respects its employees and treats them fairly and the working group climate is positive, employees tend to be in a good mood. Sloat (1999) suggests that employees who have a good mood will voluntarily help other people and companies.

\subsection{Relationship between Supervisory Support and Work Life Balance}

Supervisory support has a very important role in helping employees to achieve a balance of work roles and family roles (Hammer et al., 2009). Bosses contribute to balancing the work life of employees with the lives of individual employees. Through supervisory support, employees are able to harmonize their responsibilities related to work with responsibilities within their families. Bosses provide opportunities for employees to enjoy their personal lives without reducing the obligation of employees to complete their duties at work. The results of the study by Machuca et al. (2015) show that supervisory support contributes positively and significantly to work life balance. Based on theoretical studies and the results of the research, the following hypotheses can be formulated:

H1: Supervisory support has a significant effect on work life balance

\subsection{Relationship between supervisory support and organizational citizenship behavior \\ Organizational climate is an initial condition that} can create OCB among employees (Organ, 1988). The organizational climate and organizational culture can be the cause of the quality of the development of OCB in an organization. If employees are treated spatially by superiors, employees will support the organization's goals. Bosses can create a comfortable mood and have implications for the willingness of employees to help others (George \& Brief, 1992). Mood is not only influenced by personality but also influenced by situations, such as organizational climate, support from superiors, and other organizational factors. Employees are valued in the workplace and treated fairly so employees are in a positive mood so they voluntarily provide assistance to others (Sloat, 1999). The results of previous studies indicate that supervisory support has a direct effect on OCB (Podsakoff et al., 2000; LePine et al., 2002; Yadav \& Rangnekar, 2014). The second hypothesis is as follows:

H2. Supervisory support has a significant effect on organizational citizenship behavior.

\subsection{Relationship between Work Life Balance and Organizational Citizenship Behavior}

Work-life balance is an individual perception that work and non-work activities must be commensurate and encourage growth in accordance with the individual's life priorities at this time (Kalliath \& Brough, 2008). Employees are individuals who have personal interests who do not want to be bothered by work interests, and vice versa. So that the balance between personal life and work life is a concern for employees and companies. Employees who feel they have a good work life balance feel that they are in a comfortable work environment that creates positive behaviors that contribute to the company. This is relevant to the opinion of Baral and Bhargava (2008) who argue that work life balance has implications for attitudes, employee good behavior is important for organizational effectiveness. Positive behavior of employees in the workplace is reflected in OCB where employees are willing to do various things for the organization they work in, beyond what is their duty and obligation. Raddaha (2012) and Masum et al. (2016) have proven the effect of work life balance 
on organizational citizenship behavior. Based on the explanation above, the following hypotheses can be formulated:

H3: Work Life Balance has a significant effect on Organizational Citizenship Behavior.

\section{Research Methods}

Closed questionnaires are used as research instruments. The questionnaire contains questions about the characteristics of respondents and items related to the research variable. The Supervisory Support dimension according to Mohamed and Ali (2016) includes 3 things, namely respecting views and ideas of employees, collaborative approach in supervision, and safe feedback. Respecting the views and ideas of the employees is to respect and appreciate the views or ideas of employees. Collaborative approach in supervision, namely supervision that involves employees to find the best solution. Safe feedback is an award by the leadership towards the input of employees to improve the organization. Kula and Guler (2014) supervisory support measures include welfare, pay attention, get job done, work together, credit for well, criticize, dan backup. The indicator of this study was adapted from the indicators developed by Mohamed and Ali (2016) and Kula and Guler (2014).

Work-life balance measurements in research adapted from Clark (2000) include: (1) Border is an employee who has the opportunity to do his personal work without reducing his duties and responsibilities as an employee; (2) Permeability is an employee has the opportunity to take emergency actions for his personal interests without reducing the duties and responsibilities as an employee; (3) Flexibility, that is, the company provides opportunities for employees to work flexibly so that employees are able to balance work with their personal lives; and (4) Blending means that employees are given the opportunity to combine work assignments while living their personal lives.

According to Organ (1988), OCB is built from five dimensions, each of which is unique, namely: (1) altruism, helping others to do their work; (2) conscientiousness, which is about the performance of the role prerequisites that exceed the minimum standards, for example not absent from work days; (3) civic virtue is participating behavior and showing concern for the survival of the organization; (4) sportsmanship is showing willingness to tolerate unfavorable conditions without complaining; and (5) courtesy is behavior that is polite and in accordance with the rules so as to prevent interpersonal conflicts from arising. Meanwhile Smith et al. (1983) states that OCB involves several behaviors such as helping others, volunteering for extra tasks, obeying the rules and procedures in the workplace. These behaviors illustrate "the employee added value" and is one of the forms of prosocial behavior, the social behavior of positive, constructive and meaningful help. Graham (1991) proposed three forms of OCB, namely: (1) obedience that describes the willingness of employees to accept and comply with organizational rules and procedures; (2) loyalty that reflects the willingness of employees to place their personal interests for the benefit and continuity of the organization; (3) participation which describes the willingness of employees to actively develop all aspects of organizational life. Participation consists of social participation, advocacy participation, and functional participation. Podsakoff et al. (2000) divide OCB into seven dimensions, namely: (1) helpful behavior; (2) compliance with the organization; (3) sportsmanship; (4) loyalty to the organization; (5) individual initiatives; (6) social quality; and (7) self development. Finally the indicator of this study adapts to the Organ indicator (1988).

All research variables were measured using a graded Likert scale between scores 1 to 5 ("strongly disagree" to "strongly agree"). The instrument test was carried out on 30 respondents and the results showed that the overall item had a validity coefficient above 0.3 and Cronbach's Alpha (reliability) was greater than 0.6 so the questionnaire could be used for subsequent data collection. The unit of analysis of this study is permanent employees who work in star hotels. Data was collected from two five-star hotels and seven four-star hotels in the city of Malang, East Java, during the simple randomly selected June-July 2018. It is known that the total population of the study was 439 employees. 209 sample sizes are determined based on the Slovin formula. The sampling technique used was proportionate stratified random sampling, namely choosing respondents proportionally and randomly based on the stratification of positions. Questionnaires were given to respondents who had been chosen randomly.

\section{Results}

\subsection{Respondent profile and confirmatory factor analysis}

Most of the respondents were male $(64.6 \%$ male and $35.4 \%$ female) and most were young $(\leq 25$ years old $15.8 \%$; $26-35$ years old $47.4 \%$; $36-45$ years old $23.9 \%$ ); and $\geq 46$ years $12.9 \%$ ). The majority of respondents were married (married 76.6\%; not married $23.4 \%$ ) and had a relatively short tenure (length of employment $\leq 10$ years $80.9 \%$ ); 11 20 years $18.2 \% ; 21-30$ years $0.5 \%$; and $\geq 30$ years $0.5 \%)$.

Crosscheck validity and reliability using convergent validity and discriminant validity. Table 1 shows the results of the analysis of the 2 nd order measurement model and all dimensions produce a loading factor greater than 0.6 and the AVE root 
value in each dimension is greater than the correlation coefficient between dimensions. Thus convergent validity and discriminant validity of all indicators are stated to be fulfilled. behavior by $73.1 \%$, while the remaining $26.9 \%$ is the contribution of other variables not discussed in this study.
Table 1. Validity and Reliability Test Results

\begin{tabular}{|c|c|c|c|c|c|}
\hline $\begin{array}{l}\text { Variable } \\
\text { and } \\
\text { Dimension }\end{array}$ & $\begin{array}{l}\text { Loadi } \\
\text { ng }\end{array}$ & SE & $\mathbf{C R}$ & AVE & $\begin{array}{l}\text { Cronb } \\
\text { ach's } \\
\text { alpha }\end{array}$ \\
\hline \multicolumn{6}{|c|}{ Supervisory Support } \\
\hline & & & & & \\
\hline $\begin{array}{l}\text { and Ideas } \\
\text { of The }\end{array}$ & 0.910 & 0.016 & $57.25^{*}$ & 0.935 & 0.930 \\
\hline \multicolumn{6}{|l|}{ Employees } \\
\hline \multicolumn{6}{|l|}{$\begin{array}{l}\text { Collaborati } \\
\text { ve }\end{array}$} \\
\hline $\begin{array}{l}\text { Approach } \\
\text { in }\end{array}$ & 0.928 & 0.012 & $77.16^{*}$ & 0.901 & 0.890 \\
\hline \multicolumn{6}{|l|}{ Supervision } \\
\hline $\begin{array}{l}\text { Safe } \\
\text { Feedbacks }\end{array}$ & 0.927 & 0.013 & $72.02^{*}$ & 0.915 & 0.907 \\
\hline Welfare & 0.932 & 0.012 & $79.71^{*}$ & 0.944 & 0.940 \\
\hline \multicolumn{6}{|c|}{ Work Life Balance } \\
\hline Border & 0.870 & 0.020 & $42.65^{*}$ & 0.879 & 0.861 \\
\hline $\begin{array}{l}\text { Permeabilit } \\
\text { y }\end{array}$ & 0.872 & 0.023 & $38.11^{*}$ & 0.888 & 0.873 \\
\hline Flexibility & 0.907 & 0.014 & $63.71^{*}$ & 0.863 & 0.841 \\
\hline Blending & 0.907 & 0.016 & $55.71^{*}$ & 0.844 & 0.813 \\
\hline
\end{tabular}

Organizational Citizenship Behavior

\begin{tabular}{|c|c|c|c|c|c|}
\hline Altruism & 0.736 & 0.046 & $15.9^{*}$ & 0.935 & 0.931 \\
\hline Courtesy & 0.844 & 0.02 & $41.4^{*}$ & 0.829 & 0.787 \\
\hline $\begin{array}{l}\text { Conscientio } \\
\text { usness }\end{array}$ & 0.896 & 0.014 & $64.51^{*}$ & 0.891 & 0.877 \\
\hline $\begin{array}{l}\text { Sportsman } \\
\text { ship }\end{array}$ & 0.906 & 0.013 & $68.26^{*}$ & 0.806 & 0.760 \\
\hline $\begin{array}{l}\text { Civic } \\
\text { Virtue }\end{array}$ & 0.826 & 0.025 & $33.22^{*}$ & 0.865 & 0.842 \\
\hline
\end{tabular}

$*$ p-value $<0.05$

\subsection{Structural equation model}

The analytical tool used in this study is GeSCA. Goodness of fit model in this study is used to test the feasibility of the construct model that is formed. The test index used in the GSCA analysis is Fit, GFI, and SRMR. The results show that GFI is $0.973 \geq$ cut off value (amounting to 0.9) then the construct formed is appropriate (decent or good fit). SRMR $(.079) \leq$ cut off value (0.08) then the construct formed is appropriate (decent or good fit). The Fit value of 0.731 shows that the diversity of organizational citizenship behavior can be explained by the overall model of $73.1 \%$, or in other words, the overall contribution of supervisory support and work life balance variables to organizational citizenship

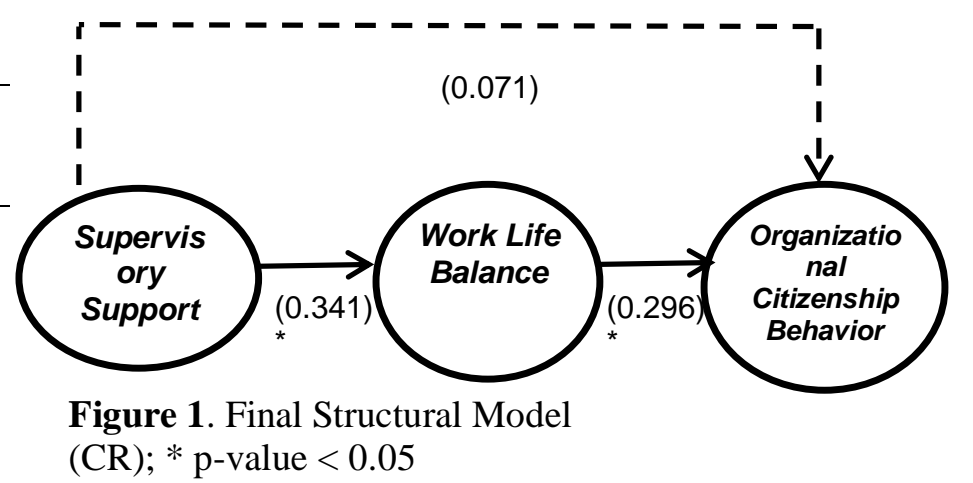

Hypothesis testing is done by comparing the critical ratio (CR) with t-table. The hypothesis is accepted if CR has a greater value than t-table. Hypothesis 1 states that supervisory support has a significant effect on Work Life Balance. The results show that the $C R$ value of 3.73> 2.00 (t-table) can be concluded that supervisory support has a significant effect on Work Life Balance and Hypothesis 1 is accepted.

Hypothesis 2 states that supervisory support has a significant effect on organizational citizenship behavior. The results show that the CR value is 0.91 $<2.00$ (t-table), it can be concluded that supervisory support does not significantly influence organizational citizenship behavior and Hypothesis 2 is rejected.

Hypothesis 3 states that Work Life Balance influences organizational citizenship behavior. The results show that the $\mathrm{CR}$ value of 3.79>2.00 (t-table) can be concluded that Work Life Balance has a significant effect on organizational citizenship behavior and Hypothesis 3 is accepted.

Table 2. Hypothesis testing

\begin{tabular}{lllll}
\hline $\begin{array}{l}\text { Independent } \\
\text { Variables }\end{array}$ & $\begin{array}{l}\text { Dependent } \\
\text { variable }\end{array}$ & Estimate & SE & CR \\
\hline $\begin{array}{l}\text { Supervisory } \\
\text { Support }\end{array}$ & $\begin{array}{l}\text { Work Life } \\
\text { Balance }\end{array}$ & 0.341 & 0.091 & $3.73^{*}$ \\
$\begin{array}{l}\text { Supervisory } \\
\text { Organizational }\end{array}$ & $\begin{array}{l}\text { Citizenship } \\
\text { Behavior } \\
\text { Organizational }\end{array}$ & 0.071 & 0.078 & 0.91 \\
$\begin{array}{l}\text { Work Life } \\
\text { Balance }\end{array}$ & $\begin{array}{l}\text { Citizenship } \\
\text { Behavior }\end{array}$ & 0.296 & 0.078 & $3.79^{*}$ \\
\hline$*$ p-value < 0.05; FIT $=0.721$; GFI = 0.973; SRMR = \\
0.079
\end{tabular}

\section{Discussion and Conclusion}

This study aims to investigate the effect of supervisory support on Work Life Balance. The results of the study show that supervisory support plays an important role in improving Work Life 
Balance. The results of this study are consistent with Hammer et al. (2009), which states that supervisory support helps employees to achieve a balance of work and family roles. Through supervisory support, employees can align work responsibilities with family responsibilities. The results of this study also support the study of Machuca et al (2015) that supervisory support has a positive relationship on employee work life balance. Based on these findings, the company needs to design a principal task that has functions such as to support subordinates in achieving goals. The form of support can be in the form of technical support and psychological support so that employees are able to achieve the targets set by the company and have a happy feeling when carrying out the task. High job demands at the hotel can create work stress and create discomfort in the workplace that has the potential to disrupt the personal life of employees in the family. Through supervisory support, work stress is reduced so that the work life and personal life of employees will be balanced.

This study also aims to investigate the effect of supervisory support on organizational citizenship behavior. The results showed that supervisory support had no significant effect on organizational citizenship behavior. The results of this study do not provide empirical evidence on the Social Exchange Theory (Blau, 1964) which states that in social interactions if one party benefits then it will try to return the favor. In the context of this study the benefits provided by the company to employees in the form of supervisory support were positively responded to by employees but the effect was not real. Supervisory support does not significantly affect employee behavior that is profitable for the company such as willingness to help coworkers, participate in helping the company, willingness to work beyond standards, avoid conflict, and other behaviors that benefit the company. The results of this study are not in accordance with the results of research from Yadav and Rangnekar (2014) and Suan \& Nurdin (2013) which states that strong organizational citizenship behavior can be built from strong support from the leaders. In the context of this study, supervisory support has no significant effect on organizational citizenship behavior because most of the respondents are highly educated so the supervisory support role is not too important in directing OCB. The higher the education level of the employee, it is possible for employees to have high knowledge and insight, so that the role of supervisor support is not necessary.

This study also aims to investigate the effect of Work Life Balance on Organizational Citizenship Behavior. The results of this study indicate that Work Life Balance has a significant effect on Organizational Citizenship Behavior. The balance between the role of employees in work and the role of employees in the family has a positive effect on employee behavior in the workplace in the form of extra behaviors outside of their main tasks, such as helping coworkers, providing important information for organizational continuity, volunteering working outside the main task without reward. and other behaviors that help organizational goals. Such employee behavior is important in realizing company competitiveness because companies are more efficient and companies obtain important information from employees that have the potential to harm the company. The results of this study can be taken into consideration for companies to implement programs directed at realizing work life balance, such as recreation, family gatherings, scholarship programs for families of employees, and other relevant programs.

Our conclusions show that Supervisory Support has a significant effect on Work Life Balance, Work Life Balance has a significant effect on Organizational Citizenship Behavior, but Supervisory Support does not directly influence Organizational Citizenship Behavior. These results indicate important findings related to the role of Work Life Balance as a mediator of the relationship between Supervisory Support and Organizational Citizenship Behavior. Good Supervisory Support creates Work Life Balance among employees so that it will enhance Organizational Citizenship Behavior.

This study has limitations so it provides recommendations for further research. First, this study has not examined respondents' characteristics such as age, gender, education, and marital status which can have different effects on Supervisory Support, Work Life Balance, and Organizational Citizenship Behavior. Subsequent research is recommended to include demographic factors in the study. Second, this study is cross sectional so it is recommended to conduct longitudinal research so that it can be compared between times.

\section{References}

Bacharach, S. B \& Bamberger, P.A. (2007). 9/11 and New York City Firefighters Post Hoc Unit Support and Control Climates: A Context Theory of the Consequences of Involvement in Traumatic Work-Related Events. Academy of Managerial Journal, 50 (4) pp. 869-868

Baral, R \& Bhargava, S. (2008). Work Family Enrichment as A Mediator Between Organizational Interventions for Work life Balance and Job Outcomes. Journal of Managerial Psychology, 25(3) pp.274-300

Bhate, R. (2013). Supervisor supportiveness: Global Perspectives. The Sloan Center on Aging \& Work at Boston College

Blau, P.M. (1964). Exchange and Power in Social Life. New York: John Wiley \& Sons. 
Colquitt, J., LePine, J., \& Wesson, M. (2015), Organizational Behavior: Essentials for Improving Performance and Commitment (1sted.). New York: The McGraw-Hill Companies Inc

Clark, S.C. (2000). Work/family border theory: A new theory of work/family balance. Human Relations Journal, 53 (6) Pp. 747-770

Delecta, P. (2011). Work Life Balance. International Journal of Current Research, 33 (4): 186-189

Frame, P. \& Hartog, M. (2003). From rhetoric to reality. Into the swamp of ethicallpractice: implementing work-life balance. Business Ethics: A European Review, 12 (4) pp. 358-367

George, J.M. \& Jones, G.R. (2012), Organizational Behavior, Understanding and Managing, Sixth Edition, Pearson Education Prentice Hall: New Jersey.

Gillet, N., Gagné, M., Sauvagère, S., \& Fouquereau, E. (2013). The role of supervisor autonomy support, organizational support, and autonomous and controlled motivation in predicting employees' satisfaction and turnover intentions. European Journal of Work and Organizational Psychology, 22(4) pp. 450-460.

Graham, J. W. (1991). An Essay on Organizational Citizenship Behaviour. Employee Responsibilities and Rights Journal, 4 (4) pp. 249-270.

Hammer, L. B., Kossek, E. E., Yragui, N. L., Bodner, T. E. \& Hanson, G. C. (2009). Development and validation of a multidimensional measure of family supportive supervisor behaviors (FSSB). Journal of Management, 35(4) pp. 837-856.

Jan, Z. \& Gul, A. (2016) Strategic Use of Organizational Citizen Behavior. A Tool for Gaining Competitive Advantage. International Journal of Economics, Commerce and Management, 4 (6).

Karatepe, O.M. (2006). Customer complaints and organizational responses: the effects of complainants' perceptions of justice on satisfaction and loyalty. International Journal of Hospitality Management, 25 (1) pp. 69-90.

Karatepe, O.M., Yavas, U. \& Babakus, E. (2007). The effects of customer orientation and job resources on frontline employees' job outcomes. Services Marketing Quarterly, 29(1) 1 pp.61-79.

Kula, S \& Guler, A. (2014). Influence of Supervisor Support on Job Satisfaction Levels: An Evaluation of Turkish National Police (TNP) Officers in Istanbul Police Department". International Journal of Criminal Justice Sciences, 9 (2) pp. 209-224

Kalliath, T. \& Brough, P. (2008). Work Life Balance: A Review of The Meaning of The Balance
Construct, Journal of Management and Organization, 14(3) pp. 323-327

LePine, J.A., Erez, A. \& Johnson, D.E. (2002), The nature and dimensionality of organizational citizenship behaviour. A critical review and meta-analysis, Journal of Applied Psychology, 87(1) pp. 52-65.

Luthans, F. (2011), Organizational behavior: an evidence-based approach. New York: McGraw Hill- Irwin.

Lyu, Y., Zhu, H., Zhon, H. \& Leqi Hu, L. (2016). Abusive supervision and customer-oriented organizational citizenship behavior: The roles of hostile attribution bias and work engagement. International Journal of Hospitality Management, 53 (6) pp. 69-80

Machuca, M.M, Mirabent J.B \& Alegre I. (2015), "Work Life Balance and Its Relationship with Organizational Pride and Job Satisfaction". Journal of Managerial Psychology, 31 (2) pp.586-602

Mohamed, S.A \& Ali, M. (2016), The importance of Supervisor Support for Employees' Affective Commitment: An analysis of Job Satisfice. International Journal of Scientific and Research Publications, 6(2).

Muhammad, A.H. (2004), Procedural justice as mediator between participation in decision making and organizational citizenship behavior, International Journal of Commerce \& Management, 14(3) pp. 58-68.

Nadiri, H. \& Tanova, C. (2010). An investigation of the role of justice in turnover intentions, job satisfaction, and organizational citizenship behavior in hospitality industry. International Journal of Hospitality Management, 29 (10) pp. 33-41

Organ, D.W. (1988), Organizational Citizenship Behavior: The Good Soldier Syndrome Heath, Lexington, MA

Podsakoff, P.M., Mackenzie, S.B., Paine, J.B. \& Bachrach, D.G. (2000). Organizational citizenship behaviors: a critical review of the theoretical and empirical literature and suggestions for future research", Journal of Management, 26(3) pp. 513-563.

Robbins, S. \& Coulter, M. (2012). Management. 9th ed. Australia: Prentice Hall Pearson Education International.

Rea, A. (2008), Organization Behavior: An Introduction to Your Live in Organizational. United States: Person International.

Robbins, S.P. (2003). Organizational Behavior. Upper Saddle River, Prentice-Hall Inc., New Jersey.

Robbins, S. \& Coulter, M. (2012), Management. 9th ed. Australia: Prentice Hall Pearson Education International 
Schermerhorn Jr, J. R., Osborn, R. N., Uhl-Bien, M., \& Hunt, J. G. (2010), Organizational Behavior $\left(12^{\text {th }}\right.$ ed.). John Wiley \&Sons, USA.

Suan, C.L. \& Nasurdin, A.M. (2013). Role Clarity, Supervisory Support, Peer Support, and Work Engagement of Customer-Contact Employees in Hotels: A Future Research Agenda. Tourisms: An International Multidisciplinary Journal of Tourism, 8(1) pp. 315-329.

Wicks, R. J. (2005), Overcoming Secondary Stress in Medical and Nursing Practice: A Guide to Professional Resilience and Personal WellBeing. Oxford University Press, USA

Yadav M \& Rangnekar S. (2014), Supervisory Support and Organizational Citizenship Behavior". Evidence-based HRM: A Global Forum for Empirical Scholarship, 3(3) pp. 258-278

Yang, T., Shen, Y.M., Zhu, M., Liu, Y., Deng, J., Chen, Q., \& See, L-C (2016). Effects of CoWorker and Supervisor Support on Job Stress and Presenteeism in an Aging Workforce: A Structural Equation Modelling Approach. Int. J. Environ. Res. Public Health, 13(72). 